\title{
Scope and semimodal verbs: two approaches
}

\author{
Michael Richter
}

\section{Abstract: \\ Scope and semimodal verbs: two approaches}

In this paper I focus on scope phenomena connected with semimodal (and modal) verbs and mainly on the syntactic behaviour of these groups of verbs. One important question is: why can semimodal verbs (and modal verbs in epistemic use) not have perfect and future tense forms? Taking among other things Reichenbach's tense system as a starting point I try to point out that the interpretation of a semimodal or a modal in epistemic use is problematic 1 . if there is more than one reference time/if the reference time is indefinite or 2 . if the verb in question stands together with an auxiliary of future which has a certain modal meaning itself. The comparison of the treatment of these phenomena in the framework of the Semantic Syntax with a non transformational approach (fragment of a categorial grammar) shows, that some important transformational rules and principles easily and economically can be represented in a non transformational grammar. The transformational approach needs rules like RAISING and LOWERING (or at least one of the two, and in addition to this a rather extended set of rules) for the generation of sentences, while in the categorial system we need only two reduction laws. It has to be investigated whether and to what extent the formation and transformation rules in a transformational grammar on the one hand and the dominance / linear precedence rules together with the lexical entries on the other hand are equivalent.

In this paper I focus on scope phenomena connected with semimodal (and modal) verbs and mainly on the syntactic behaviour of these groups of verbs. One important question is: why can semimodal verbs (and modal verbs in epistemic use) not have perfect and future tense forms? Taking among other things Reichenbach's tense system as a starting point I try to point out that the interpretation of a semimodal or a modal in epistemic use is problematic 1 . if there is more than one reference time/if the reference time is indefinite or 2 . if the verb in question stands together with an auxiliary of future which has a certain modal meaning itself. The comparison of the treatment of these phenomena in the framework of the Semantic Syntax with a non transformational approach (fragment of a categorial grammar) shows, that some important transformational rules and principles easily and economically can be represented in a non transformational grammar. The transformational approach needs rules like RAISING and LOWERING (or at least one of the two, and in addition to this a rather extended set of rules) for the generation of sentences, while in the categorial system we need only two reduction laws. It has to be investigated whether and to what extent the formation and transformation rules in a transformational grammar on the one hand and the dominance / linear precedence rules together with the lexical entries on the other hand are equivalent.

\section{Introduction:}

Modal verbs and semimodal verbs (e.g. scheinen, drohen, pflegen, versprechen) exhibit a similar syntactic behaviour: they form a so-called verbal complex (Verbalkomplex) which is characteristic of a coherent structure (Bech 1955/57). But both groups of verbs differ in their inflectional paradigms: modal verbs can have future-, present-/past-perfect- and subjunctive- 
forms, semimodal verbs on the other hand have a defective paradigm. From a tense logical point of view I try to point out the differences between modal and semimodal verbs and I draw the conclusion that the interpretation of a semimodal or a modal verb in epistemic use is problematic 1. if there is more than one reference time and if the event time is not definite, i.e. if it does not equal the reference time or 2. if a semimodal stands together with an auxiliary of future, which has a certain modal meaning itself.

In the theoretical framework of Semantic Syntax I offer a syntactical proposal on how to treat these verbs. The syntactical correspondence is explained by the assumption that both verbtypes take a sentence as argument and that they share the transformational feature of LOWERING which makes them move down onto the $\mathrm{V}$ in the embedded sentence. The analysis of semimodal verbs as SUBJECT-RAISING verbs is thus rejected.

The inflectional difference is explained by the assumption that semimodal verbs stand in a position between the two tense operators. The modal verbs on the other hand are inside the scope of both tense operators, which accounts for the fact that they show the full inflectional paradigm.

An additional argument favouring the position of semimodal verbs between the tense operators is the fact that these verbs are not inside the scope of scope bearing elements.

No proposal is made for the treatment of finite embeddings under scheinen and drohen and for a semantic analysis of the semimodal and modal verbs.

Finally I examine the possibility of representing the treatment of semimodal verbs in the framework of a non-transformational grammar, namely a (flexible) categorial grammar. This is motivated by the attempt to reduce the set of rules and assumptions.

\section{Coherence, branching direction and tense}

Just like the modal verbs, the semimodal verbs (with the exception of finite embeddings governed by drohen and scheinen as matrix verbs) obligatorily form a coherent verbal complex. I found the categorization of these verbs as "Halbmodale" in Eisenberg (1986) and in the Grammatik der deutschen Sprache (GdS, 1997) and the equivalent English term "semimodals" in Kiss (1994). The syntactic attribute of coherence was introduced into linguistics by Gunnar Bech (1955/57). Coherent constructions are the result of the union of two or more sentences, namely of the matrix sentence and at least one embedded sentence, respectively. These unioned sentences show a typical syntactic behaviour, among other things a verbal complex which forbids other elements to press between the elements of this complex, e.g.: *..., weil er sie besuchen heute will. The Verbalkomplex consists of the finite matrix verb (which has to be a modal verb, a "verbum sentiendi," an auxiliary or a verb) and at least one subordinated infinite verbal element. In the GdS we find the following definition (1997: 2191):

KOHÄRENT sind alle integrierten Stellungsfolgen, bei denen der Infinitiv der IK (=infinitive-construction, M.R.) nicht rechts von dem in der rechten Satzklammer befindlichen übergeordneten Verb steht.

An exception are verbal complexes where the so-called "Oberfeldumstellung" has taken place, e.g. ... weil sie hat lachen müssen. In these cases the parameter "branching" for the verbal complex not only has the default value "left" but also "right" in a certain area of the structure-tree (see Seuren 1996, Hinrichs \& Nakazawa 1994; the heavy lines indicate the branching direction). 


\section{German V-cluster with default left branching German V-cluster leading to „Oberfeldumstellung“6}

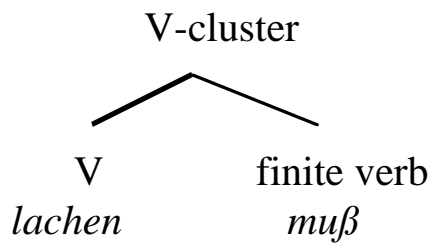

figure 1a

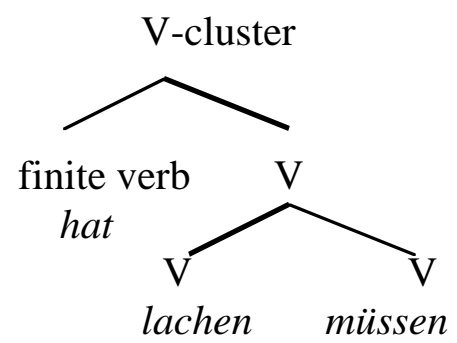

b

The uniform left branching structure 1a corresponds to the default word order in German subordinate clauses as in ..., weil sie lachen $m u \beta$ and hybrid branching $1 \mathrm{~b}$ to sentences with "Oberfeldumstellung" as in ..., weil sie hat lachen müssen.

\subsection{What do modal and semimodal verbs have in common?}

The following aspects form some of the criteria for coherence. The dependent infinitive verb can not or should not stand right of the finite verb (see the definition in GdS above). But in the intuition of some native speakers the inversion of semimodal verbs can be (marginally) well formed:

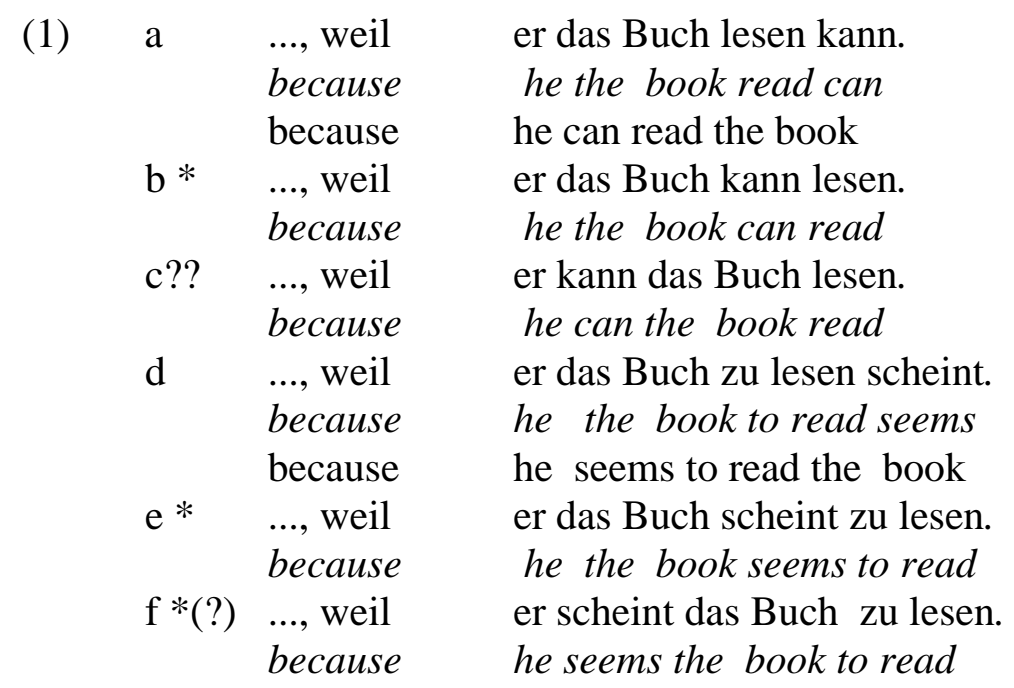

In the following examples we have extraposition of the embedded sentence (2a) and the socalled third construction (Dutch: derde constructie, German: Dritte Konstruktion) ((2)b), where the direct object of lesen has a position in middle field. In both sentences the governee, i.e. lesen, follows its governor. According to GdS this is characteristric for incoherent constructions:

(2) a ..., weil er versucht, das Buch nicht zu lesen. because he tries the book not to read because he tries not to read the book

b ..., weil er das Buch versucht zu lesen. because he the book tries to read 
In a coherent construction the so-called Wackernagel-inversion in front of the matrix subject is possible. Semimodals and modals show a identical syntactic behaviour

(3) a $\quad$..., weil sich Franz zu rasieren scheint. because himself Franz to shave seems because Franz seems to shave

b $\quad$..., weil sich Franz rasieren kann. because himself Franz shave can

A third syntactic correspondence between modal and semimodal verbs is the possibility for passivization if the embedded verb can be passivized. The embedded direct object becomes the subject ((4)a,b), which is a epiphenomenon of a coherent structure. A different behaviour is shown by a control verb in a incoherent construction ((4)c):

(4) a Der Pudding kann von mir gerührt werden.

b Der Pudding scheint von mir gerührt zu werden.

c* Der Pudding versucht von mir gerührt zu werden.

Inversion in the middle field in sentences not only with modal but also with verbs has ungrammatical results:

(5) $a^{*} \quad$..., weil sich zu rasieren Franz scheint.

b* $\quad$..., weil sich rasieren Franz kann.

c(?) ..., weil sich zu rasieren Franz behauptet / versucht.

\subsection{What do modal and verbs not have in common?}

A difference between and modal verbs is the fact that verbs from the first group allow neither future, present perfect (from now on "perfect") nor past perfect as well as subjunctive forms. A can not govern a future tense form.

(6) $a^{*} \quad$ Sie hat zu kommen geschienen.

b* Sie hatte zu kommen geschienen.

c* Sie wird zu kommen scheinen.

$\mathrm{d}^{*} \quad$ Sie wird zu kommen geschienen haben.

$\mathrm{e}^{*} \quad$ Das Rennen würde spannend zu werden scheinen.

$\mathrm{f}^{*} \quad$ Sie scheint kommen zu werden.

In the following I will leave out a treatment for the subjunctive forms. Thus the following holds:

(7) a

\section{b}

c

d *FUT PERF

e PERF

$\mathrm{f} \quad * \mathbf{F U T}$

$\begin{array}{ll}\Phi & \text { (sentence 6a) } \\ \Phi & \text { (sentence 6b) } \\ \Phi & \text { (sentence 6c) } \\ \Phi & \text { (sentence 6d) } \\ \Phi & \\ \Phi & \text { (sentence 6f) }\end{array}$

(' $\Phi '$ represents the proposition).

(7)e stands for sentences like Er scheint das getan zu haben. 


\subsection{Perfect and future}

In this paragraph I try to point out from a tense logical point of view the differences between and modal verbs, starting from the observation, as said in paragraph 2.2 , that semi-modal verbs have certain inflectional restrictions that modal verbs don't have.

The analysis of Reichenbach (1947) is our starting point. Reichenbach constructed a system for the English tense. It can be illustrated by the following scheme:

(8) a present: $\quad$ event time $=$ reference time $=$ speaking time

b simple past: $\quad$ event time $=$ reference time $<$ speaking time

c present perfect: $\quad$ event time $<$ reference time $=$ speaking time

d pluperfect: $\quad$ event time $<$ reference time $<$ speaking time

e future : $\quad$ speaking time $=\underline{\text { reference time }<\text { event time }}$

(the tenses in bold letters are excluded for the semimodal verbs in German)

Ballweg (1988) assumes an additional reference time for German (1988:89), while simple past has only one reference time:

(9) a Wir waren gestern im Theater.

b Wir sind gestern im Theater gewesen.

He gives the following time-scheme (1988:89, figure 2a shows the representation of simple past, $2 \mathrm{~b}$ the representation of perfect):

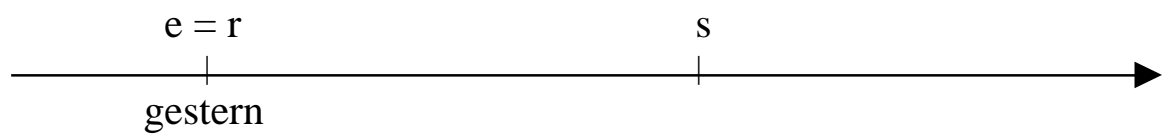

figure $2 \mathrm{a}$

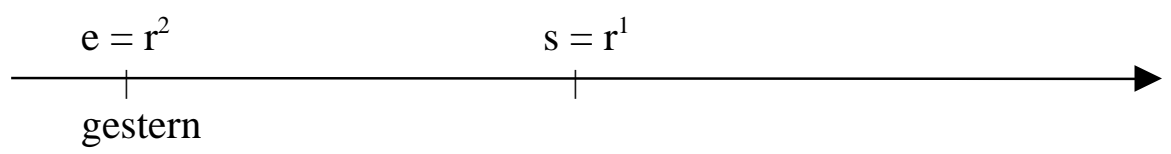

figure $2 b$

( $\mathrm{s}=$ speaking time $\mathrm{r}^{1}, \mathrm{r}^{2}=$ reference times $)$

In simple past there is only one reference time but present perfect has two reference times, i.e. $r^{l}$ which equals the speaking time and $r^{2}$, which is the event time. According to Ballweg the double reference time has the effect

[...] daß das zurückliegende Ereignis 'von der Sprechzeit her' gesehen und als besonders 'relevant für die Gegenwart' angesehen wird.

Ballweg points out that present perfect has also the feature to be syntactical ambigous witness the following two sentences (1988:88): 
(10) a Heute ist das Furiose zurückgetreten zugunsten einer auf wenige signifikante Elemente reduzierten Darstellung.

b Wir sind gestern im Schillertheater gewesen.

(10)a can be analysed as (I use Ballweg's original notation)

(10) a' Präs (heute $(\operatorname{Perf}(\alpha)))$

and (10)b as

(10) b' Präs (Perf( gestern $(\alpha)))$

This syntactic ambiguity corresponds with a semantic ambiguity when one considers a sentence like (1988:92):

(11) Bernd hat 1985 den Scheffauer bestiegen.

This sentence can have two analyses; one with narrow scope of the adverbial and an another with wide scope. The interpretation of the narraw scope variant is that the climbing up of the Scheffauer took place in 1985, while the wide scope reading says that in 1985 it has been the case that Bernd has climbed up the Scheffauer. For example, it would be possible to say on the 31. of December 1985 that the successful climb took place in 1985 or at any time earlier (1988: 93).

Following Ballweg we could assume the analysis in (12) for (11):

(12) a PRES (1985 (Perf (Bernd-den-Scheffauer-besteigen )))

b PRES (Perf (1985 (Bernd-den-Scheffauer-besteigen )))

The time-scheme of (12)a is given in figure 3a:

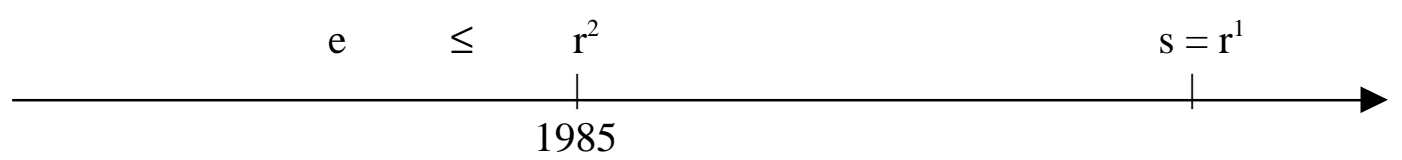

figure $3 \mathrm{a}$

The time-scheme of (12)b can be illustrated as follows:

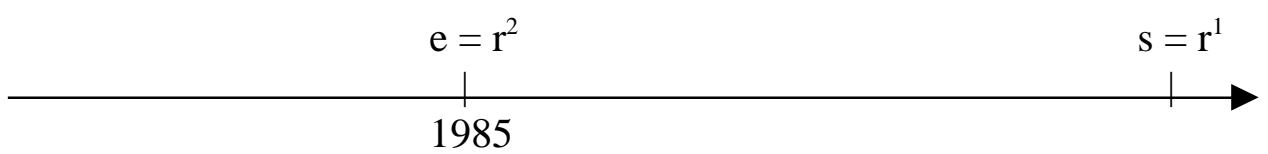

figure $3 b$

Following Ballweg in both analyses of (11) there are two reference points of time respectively. But actually the analysis (12)a is a representation of present tense in narrative usage (historisches Präsens). A possible continuation of (11) with analysis (12)a could be

(13) ... und ist auf dem Wege, der bekannteste Bergsteiger Europas zu werden.

In constrast example sentence (14)

(14) Bernd bestieg 1985 den Scheffauer. 
can only have the following time-scheme:

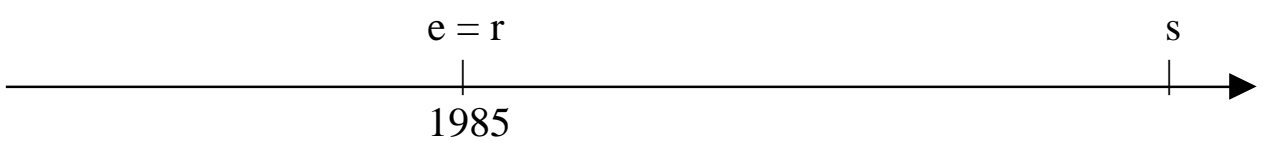

figure 4

The wide scope reading of (12) looks a little bit like examples in Nerbonne (1984). He advocates a non-compositional analysis of the perfect (1984: 156p) and argues that the evidence for the structure (1984: 156)

\section{(15) PRES (X (PERFECT-ASPECT(p)))}

is not very strong because sentences like (Nerbonne's example sentence (26) is here cited as (16)):

(16) Seit zwei Stunden hat er seine Jacke ausgezogen.

are actually genuine present tense forms (1984: 158, historisches Präsens, see above). The perfect-aspect is analyzed by Nerbonne of having a "special and noncompositional meaning", since perfect can have definite and indefinite reference to time (1984: 156) as (17) shows ((22) in Nerbonne (1984)):

(17) Er hat gelacht.

In a given dicourse an event expressed in (17) should refer to a definite time interval in the past. Nerbonne argues that an indexical treatment of tense, i.e. the anchoring of event or reference in a certain context allows tense to have scope over propositions. This treatment avoids problems of interpretation in sentences like (Enç 1981: 98)

(18) Tom went out but will be back shortly.

where we have different event times. Enç (1981: 61) argues against a scope analysis of tenses and states that the interpretations of nouns and verbs have to be independent and indexical. Evidence comes from sentences like

(19) At least two representatives of this firm will get rich.

(19) could get the following analyses:

(20) a $\mathrm{F} \exists 2 \mathrm{x}$ [representative $(\mathrm{x}) \wedge$ get-rich(x)]

$\mathrm{b} \exists 2 \mathrm{x}$ [representative $(\mathrm{x}) \wedge \mathrm{F}$ get-rich $(\mathrm{x})$ ]

These analyses don't represent all possible meanings of (20). Enç advocates an indexical treatment so that e.g. "representative" in (19) could denote sets of human beings in a (from the tense) independent certain interval of time. By representative we could mean e.g. people who are now not representatives but also representatives in the future and vice versa. ${ }^{1}$ In the

\footnotetext{
${ }^{1}$ Enç (1981:62) gives the following example:
} 
following, however, I'll try to show that a scope analysis of tense has a certain explanatory value.

Ballweg and Nerbonne agree in stating that the differences between simple past and perfect are small. But they are actually existing. For example it does not hold that PRET $\rightarrow$ PERF but PERF $\rightarrow$ PRET does (Oversteegen 1988: 130):

(21) a er hat einen Apfel gegessen b er aß einen Apfel

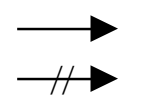

er aß einen Apfel

er hat einen Apfel gegessen

A possible continuation for the simple past sentence in (21)b could be ... warf ihn aber nach wenigen Bissen weg, um die Hände in den Manteltaschen zu wärmen. So the apple has not been eaten. But er hat einen Apfel gegessen infers that there was a time when he ate the apple. Consider also the following sentences:

(22) a Heute morgen schien er gestern tüchtig gearbeitet zu haben.

$b^{*}$ Heute morgen schien er gestern tüchtig zu arbeiten.

We see here very clearly that the time adverbial "gestern" does not have scope over the perfect-tense. This could be evidence for Nerbonne's non-compositional treatment. If the adverbial had scope over the perfect then it would affect the reference time, which would then be yesterday. But this is the case in $(22) \mathrm{b}$ : the first reference time is the morning of today and the second is yesterday. But then the sentence can't be interpreted.

We get the following two analyses for (22)a and (22)b:

\section{(22) a' heute morgen (PRET ( (PERF (gestern (er arbeiten)))))}

A tree structure for (22)a' looks like this:

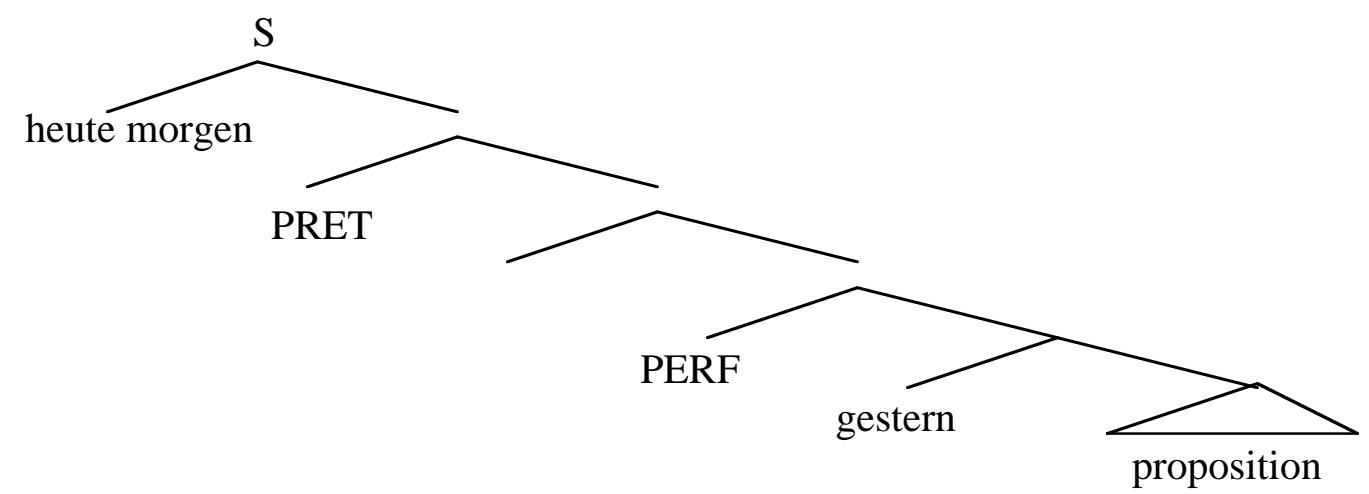

figure $5 \mathrm{a}$

and the resulting time-scheme of (22)a' is the following:

$\underset{\text { gestern }}{\mathrm{e}^{2}=\mathrm{r}^{2}} \stackrel{\mathrm{e}^{1}=\mathrm{r}^{1}}{\text { heute morgen }} \underset{\longrightarrow}{\mid}$

[...] Tom is a representative now but will not be in the future, and he will get rich in the future. Futher suppose that Harry is not a representative now but will be one in the future, and that he too will get rich. [...] This reading will be especially salient, for example, if we wish to indicate that if someone works for this firm, it is possible that he will get rich. To represent this reading, we must allow the quantifier to range over present and future representations, an option not available to us under the traditional account. 
figure $5 b$

The event $\mathrm{e}^{1}$ is that he seemed to have worked, and the reference time is the morning of today. Event $\mathrm{e}^{2}$ is the work itself and the reference time is yesterday.

The perfect seems to be a barrier for the embedded reference time. In contrast, the ungrammatical sentence (22)b can be analysed as follows:

(22) b' heute morgen (PRET ( (gestern (er arbeiten))))

(22)b can be represented as a tree structure:

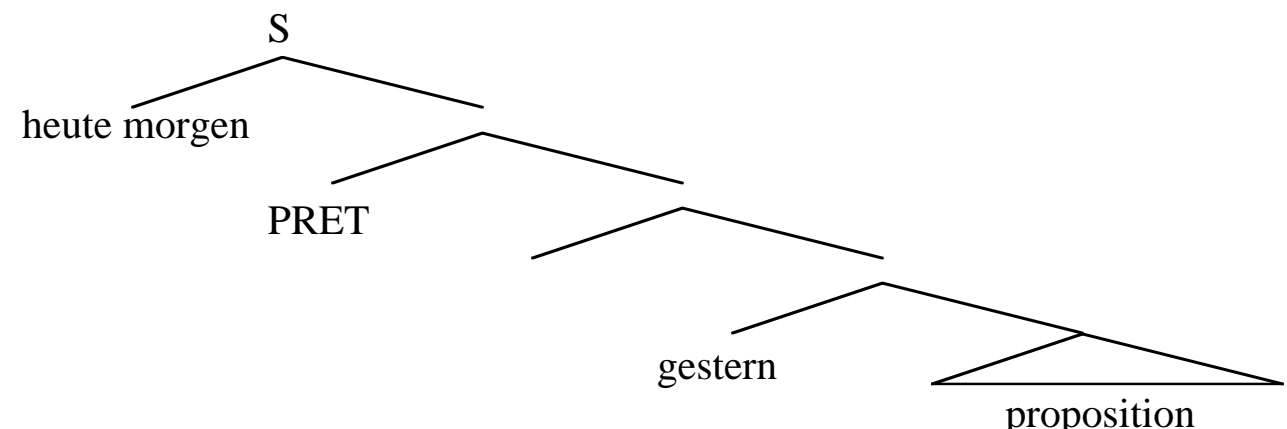

figure 6a

We can assume the following time scheme for (22)b:

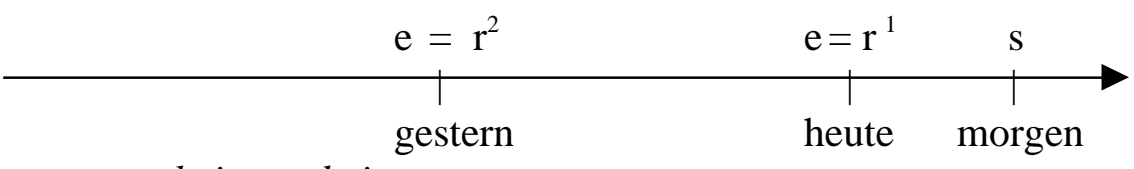

$\mathrm{e}=z u$ arbeiten scheinen

figure $6 \mathrm{~b}$

As figure $6 \mathrm{~b}$ illustrates, the paradoxical situation exists in $(22) \mathrm{b}$, that e (=he seemed to work) takes place simultaneously in the morning of today $\left(\mathrm{r}^{1}\right)$ and yesterday $\left(\mathrm{r}^{2}\right)$. Of course, the sentence is not interpretable.

Now consider the following sentences with modal verbs in epistemic usage:

(23) a Heute morgen wollte er gestern tïchtig gearbeitet haben.

$b^{*}$ Heute morgen wollte er gestern tüchtig arbeiten.

We see the same distribution as in (22), since in (23)a/b, as well, the perfect seems to be a barrier for the embedded reference time. (24) shows that a and a (epistemic) modal can't have perfect forms:

(24) $a^{*}$ Heute morgen hat er gestern tüchtig gearbeitet haben wollen.

$b^{*}$ Heute morgen hat er gestern tüchtig gearbeitet zu haben geschienen.

(24)a in epistemic use means that he claims that he worked yesterday. The speaker however doubts that. In both sentences the speaker gives an interpretation of a situation: in (24)a he has doubts and in (24)b he says that a certain event is uncertain. Moreover, in (24)b according to (8) the reference time equals the speaking time, but there is also a second reference time (see Ballweg above), i.e. the morning of today. It seems that in those cases the interpretation of a and of a modal verb in epistemic usage is difficult. The analysis of (24)a/b is: 
(24) a/b' heute morgen (PRES (PERF(/(epistemic)modal (PERF (gestern (er arbeiten)))))) The time scheme of (24) can be illustrated as follows:

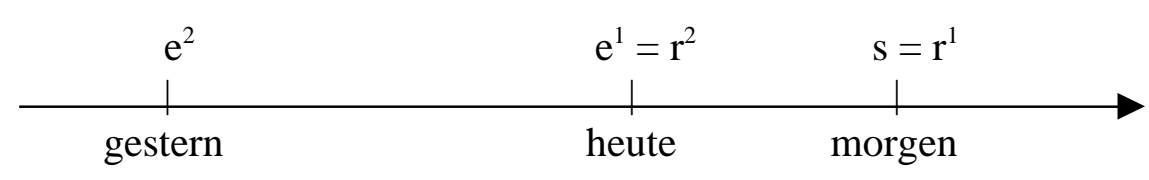

figure 7

Consider sentences with event time in the future like:

(25) $a^{*}$ Er wird die Prüfung (am Freitag) zu machen scheinen.

b Er scheint die Prüfung (am Freitag) zu machen.

Clearly, (25)b is preferable. Actually we have here present tense since speaking time, reference time and event time are identical. The speaker has now the impression that someone will take the examination on Friday. According to (8) it is hard to decide, why (25)a is ungrammatical since the reference time equals the speaking time and the speaking time precedes the event time. But isn't it possible to assume a second reference time, i.e. Friday? In this case, in (25)a the same reasons for ungrammaticality as in (24)would be valid.

In addition, the auxiliary of the future werden has a certain modal function. Janssen (1988) points out that auxiliaries of the future (for English and Dutch) are denoting a "modal event at the present time". Janssen refers to Vater (1975) who analyses the German auxiliary werden as a modal verb (1975:94) and not as an auxiliary of tense:

Die Konstruktion werden + Infinitiv Präsens ist grundsätzlich in ihren Zeitbezügen undifferenziert: Sie läßt - ebenso wie das einfache Präsens - Bezug auf Gegenwärtiges zu, wobei Gegenwartsbezug immer dann auftritt, wenn auch das einfache Präsens Gegenwartsbezug hat und Zukunftsbezug dann, wenn auch das einfache Präsens Zukunftsbezug hat.

An indefinite reference to time can be observed in sentences where the perfect is used to refer to something in the future (Nerbonne 1984: 152):

(26) a Nächsten Freitag hat er den Brief geschrieben.

then the time of the event is indefinite: it can be after the time of speaking or before the time of speaking. The interpretation of (31)a is the same as of (31)b:

(26) b Nächsten Freitag wird er den Brief geschrieben haben.

For (26)a and (26)b the following tempus-relationships hold (see Nerbonne 1984: 154):

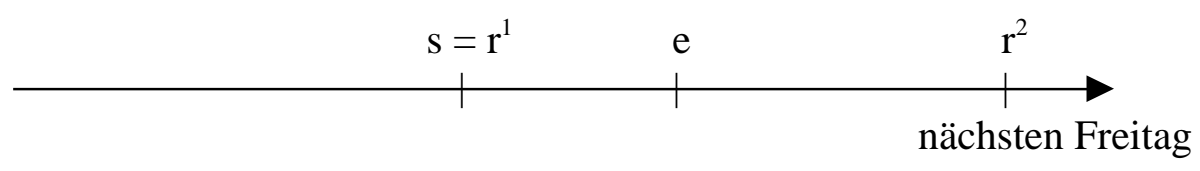

or

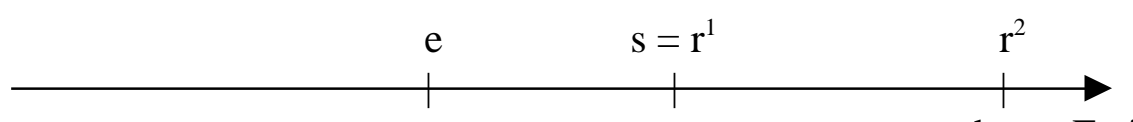

figure 9

nächsten Freitag 
But if we use a then the sentence is ungrammatical:

(27) * Nächsten Freitag wird er den Brief zu schreiben geschienen haben.

To sum up: the interpretation of a or a modal in epistemic use is problematic 1. if there is more than one reference time/if the reference time is indefinite or 2 . if the verb in question stands together with an auxiliary of future, which has a certain modal meaning itself.

In the following section I will demonstrate how the theory of Semantic Syntax accounts for the scope phenomena just mentioned.

\section{$3 \quad$ A transformational approach}

\subsection{Position of semimodal and modal verbs}

Traditionally, semimodal verbs - in transformational grammars - are interpreted as SUBJECT-RAISING verbs. The subject of the embedded clause moves upwards and becomes the head of a sentential structure.

But in Richter (2000) it is postulated and shown that SUBJECT-RAISING is not productive in German syntax: it is assumed that these verbs have the lexical feature of LOWERING. This is a movement which triggers a downward movement of an element. Consider the following deep structure in VSO-order:

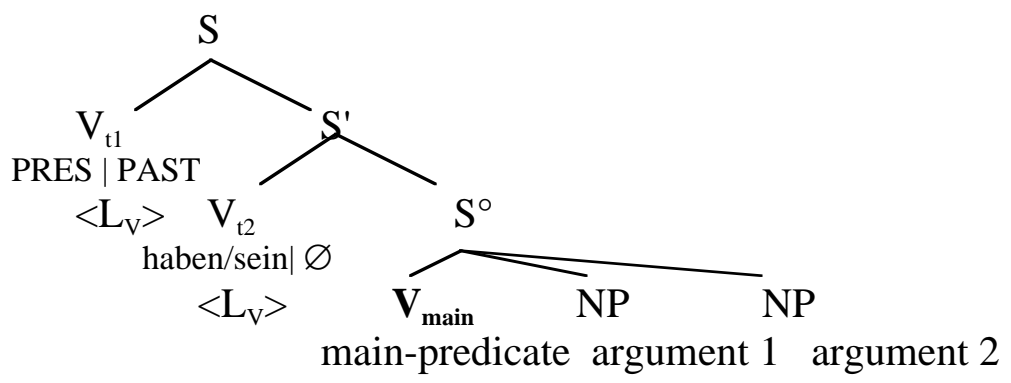

figure 10

This is a possible deep-structure in the framework of Semantic Syntax (Seuren 1996). The corresponding phrase-structure rules (i.e. "formation rules" in the terminology of Seuren (1996)) for the structure in figure 10 have the following design:

$$
\begin{array}{rlll}
\text { (28) } \mathrm{S}^{\prime \prime} & \rightarrow & \mathrm{V}_{\mathrm{t} 1} & \& \mathrm{~S}^{\prime} \\
\mathrm{S}^{\prime} & \rightarrow & \mathrm{V}_{\mathrm{t}} & \& \mathrm{~S}^{\circ} \\
\mathrm{S}^{\circ} & \rightarrow & \mathrm{V}_{\text {main }} & \& \mathrm{NP} \& \mathrm{NP}
\end{array}
$$

$\mathrm{S}^{\circ}$ dominates the lexical argument frame which contains the main lexical predicate $\left(\mathrm{V}_{\text {main }}\right)$ of the construction and also the obligatory syntactic environment of the main predicate. It is Seuren's intention to let the deepstructures have a predicate-argument-structure: they represent the meaning of a sentence. Hierarchies correspond to positions in the tree. For example, in figure $10 \mathrm{~V}_{\mathrm{t} 1}$ is inside the scope of $\mathrm{V}_{\mathrm{t} 2}$.

In the structure above we see two V-elements ('V' means 'predicate') with the feature " $\mathrm{L}_{\mathrm{v}}$ ". This means that the corresponding element has to be moved, to be lowered, down onto the main-predicate $\mathrm{V}_{\text {main }}$. In the figure above $\mathrm{V}_{\mathrm{t} 1}$ and $\mathrm{V}_{\mathrm{t} 2}$ are tense-predicates which form a Vcluster with $\mathrm{V}_{\text {main }}$. 
It's impossible for $\mathrm{V}_{\mathrm{t} 1}$ to have a terminal filler. This predicate is abstract in that it allows only for the non-terminal (lexical) fillers "PRES" or "PAST". For $\mathrm{V}_{\mathrm{t} 2}$ there are two options: terminal fillers, that is the auxiliaries "haben/sein" on the one hand or an empty filling (" $\varnothing ")$ on the other hand. $\mathrm{V}_{\mathrm{t} 2}$ can express the relation "simultaneous" (empty filling) or "preceding". If for example the relation is "simultaneous", the event time equals the speaking time which is $\mathrm{V}_{\mathrm{t} 1}$. Thus in this case the whole sentence would have either the tense form simple present or simple past. This principle is based on the tense system of Reichenbach mentioned above (see (8)). $\mathrm{V}_{\mathrm{t} 1}$ is the speaking time and $\mathrm{V}_{\mathrm{t} 2}$ is the reference time. The following combinations between $\mathrm{V}_{\mathrm{t} 1}$ and $\mathrm{V}_{\mathrm{t} 2}$ are possible:

$$
\begin{array}{llll}
\mathrm{V}_{\mathrm{t} 1} \text { PRES and } \mathrm{V}_{\mathrm{t} 2} \varnothing & : & \text { event time PRES (simple present) } \\
\mathrm{V}_{\mathrm{t} 1} \text { PRES and } \mathrm{V}_{\mathrm{t} 2} \text { haben/sein } & : & \begin{array}{l}
\text { event time PAST (present perfect, } \\
\text { speaking time }=\text { reference time) }
\end{array} \\
\mathrm{V}_{\mathrm{t} 1} \text { PAST and } \mathrm{V}_{\mathrm{t} 2} \varnothing & : & \begin{array}{l}
\text { event time PAST (simple past, } \\
\text { event time }=\text { reference time }
\end{array} \\
& & \begin{array}{l}
\text { speaking time) } \\
\text { event time PAST (pluperfect, event } \\
\text { time }<\text { reference time }<\text { speaking } \\
\text { time) }
\end{array}
\end{array}
$$

For the future tense Seuren assumes a position between $\mathrm{V}_{\mathrm{t} 1}$ and $\mathrm{V}_{\mathrm{t} 2}$.

The results of LOWERING of the tense-predicates in figure 10 are as follows (recall that as default, German has a left branching V-cluster) ${ }^{2}$ :

figure 11

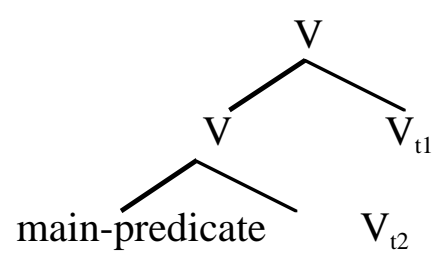

I assume that semimodal verbs have a position between the two tenses to account for the fact that these verbs, as said above, have special inflectional restrictions. The position of the semimodals in figure 11 which is $\mathrm{V}_{\text {Inter }}$ is outside the scope of the auxiliaries of time:

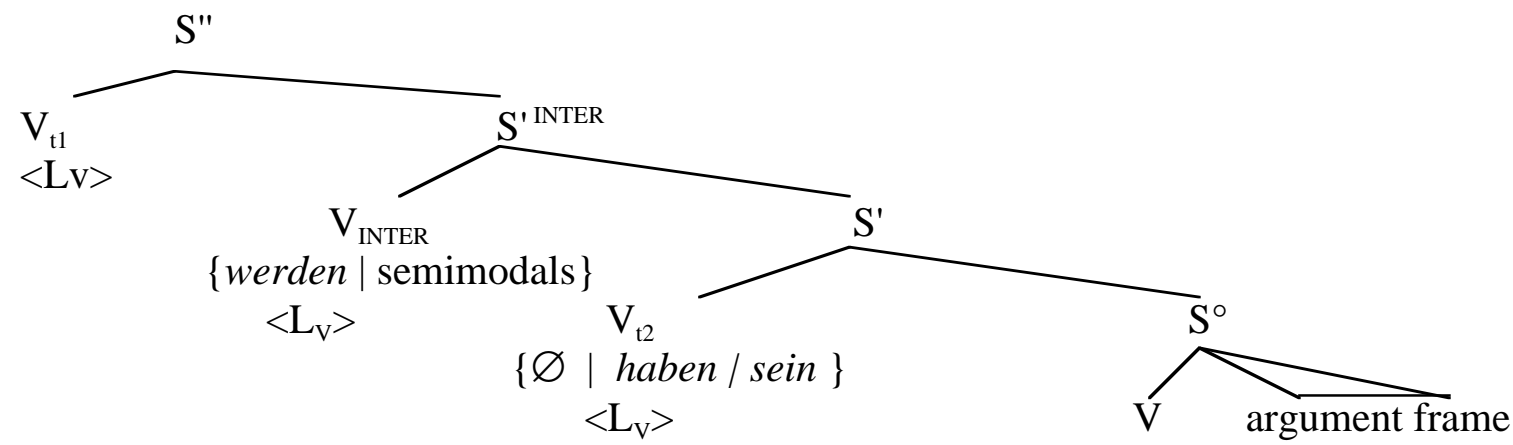

figure 12

\footnotetext{
${ }^{2}$ For the precise mechanisms of LOWERING see Seuren 1996. 
$\mathrm{V}_{\text {inter }}$ can be filled with a semimodal verb, but also with werden which in this case is the auxiliary of the future. Both groups are outside the scope of $\mathrm{V}_{\mathrm{t} 2}$. Hence it is predicted that the semimodal cannot have these tense forms.

Consider the sentence sie scheint ihn zu erwarten. The corresponding deep structure can be something like the following:

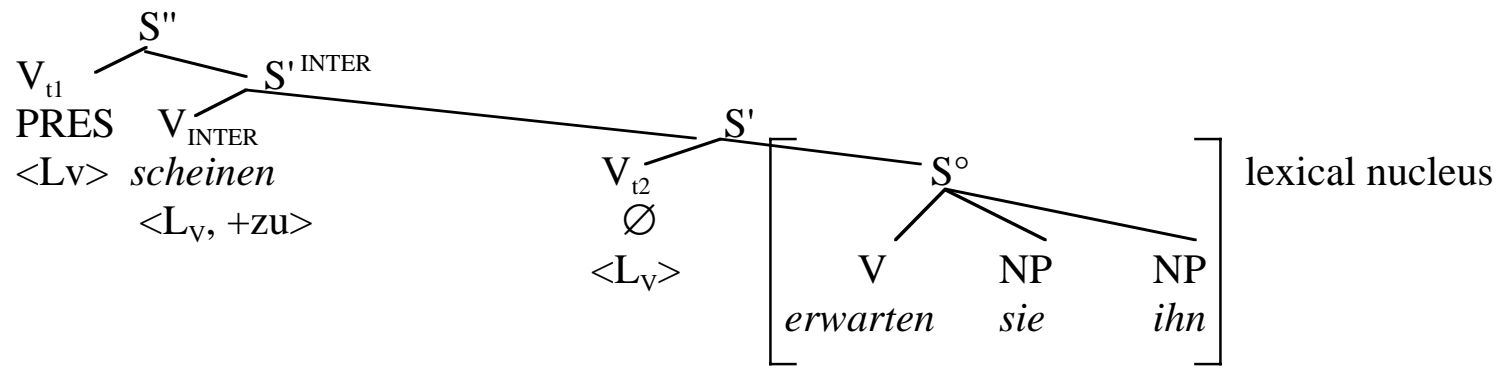

figure 13

We get a left-branching V-cluster with scheinen as highest verb and with [Aff PRES] as highest node. Remember that $\mathrm{V}_{\mathrm{t} 1}$ contains tense-information for the finite verb. After LOWERING $\mathrm{V}_{\mathrm{t} 1}$ onto the V-cluster it's label changes into "Aff". Thus the cluster is dominated by [AFF PRES]. This is an indication for the morphological generating system that the highest lexical predicate in the surface structure has to be finite.

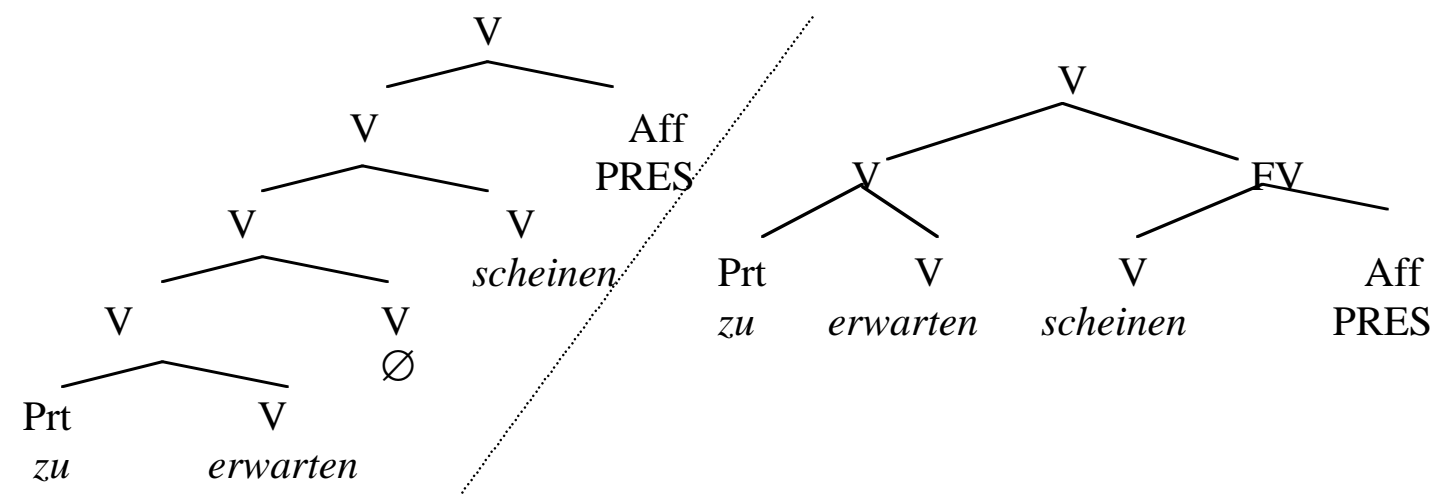

figure $14 \mathrm{a}$

$14 \mathrm{~b}$

Figure 14a shows the V-cluster after all LOWERING operations. In 14b a 'cleaning up'operation has taken place. The non relevant $\left.{ }_{\mathrm{V}} \varnothing\right]$-node has been deleted and the highest predicate $\left[_{\mathrm{V}}\right.$ scheinen] together with ${ }_{\mathrm{Aff}}$ PRES] form a node labelled "FV" which stands for "Finite Verb".

Modal verbs on the other hand are assumed to be inside of the scope of the tense operators since they have the full inflectional paradigm. De default case is that modal verbs have a sentential argument, which is the only argument.

Recall the sentences in $(8) a / b$.

(8) a ..., weil er das Buch nicht [zu lesen scheint].

b ..., weil er das Buch nicht [lesen kann]. 
Because of respective different scope of the negation in these two sentences we have to assume respective different deep structures which fit perfectly in the SeSyn system (Seuren 1996. Deep structure of (8)a:

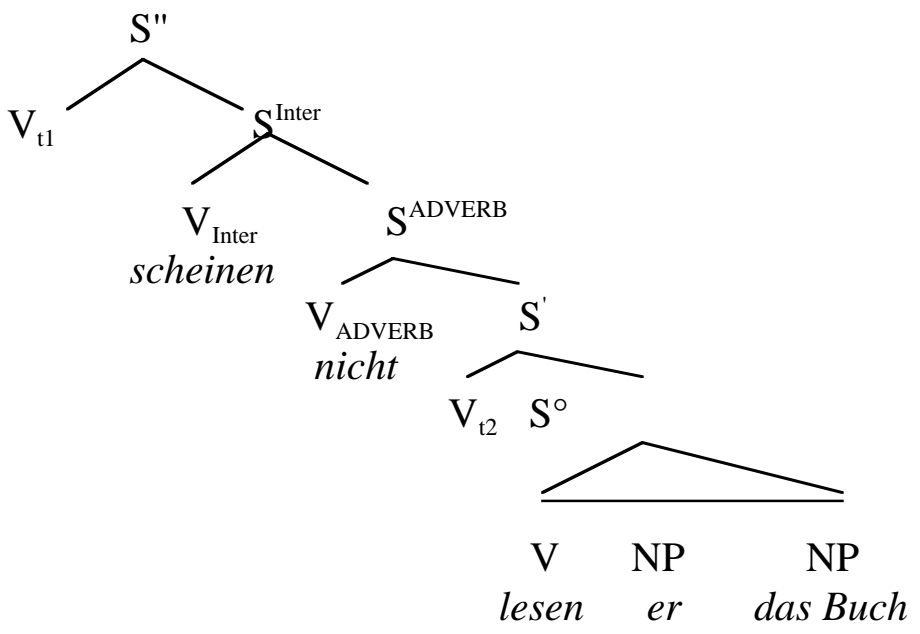

figure $15 \mathrm{a}$

Deep structure of (8)b:

figure $15 b$

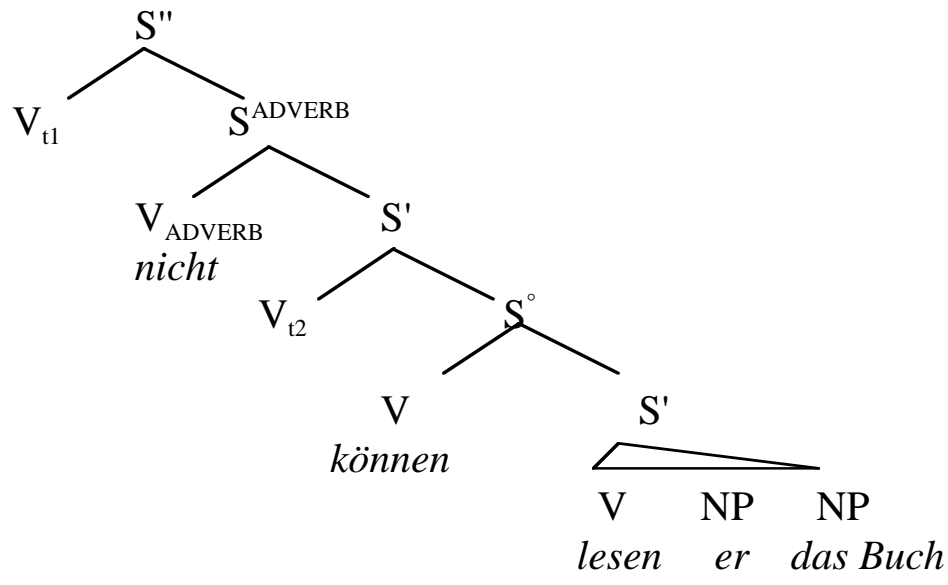

The structure 15a shows clearly that in (7)a the semimodal is not in the scope of the negation. In $15 \mathrm{~b}$ on the other hand the negation and the tense operators have scope over the modal verb. We saw above that under epistemic use not all tense forms for modal verbs are possible.

\subsection{Two transformations and one result}

The problem we are confronted with is that there is one result, namely a verbal complex and two different transformations (PREDICATE RAISING and LOWERING) leading to it. So first we have two different movements that lead to the same syntactical result (a verbal cluster inside of a coherent construction) and the assumption of two different movements for the respective head nodes, which are filled by modal verbs and semimodal verbs respectively $(\mathrm{PR}=$ PREDICATE RAISING, $\mathrm{L}_{\mathrm{v}}=$ LOWERING to verb): 


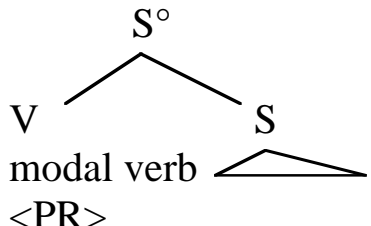

figure $16 \mathrm{a}$

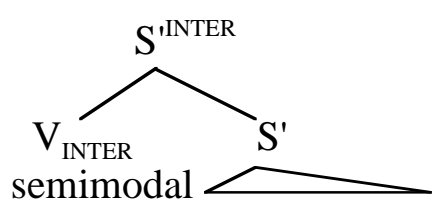

$<\mathrm{L}_{\mathrm{V}}>$

$16 b$

We see here two head nodes with two different respective transformational features. A modal verb causes PREDICATE-RAISING and a semimodal is lowered onto the V-cluster. The result in each of the two cases is the same:

figure 17

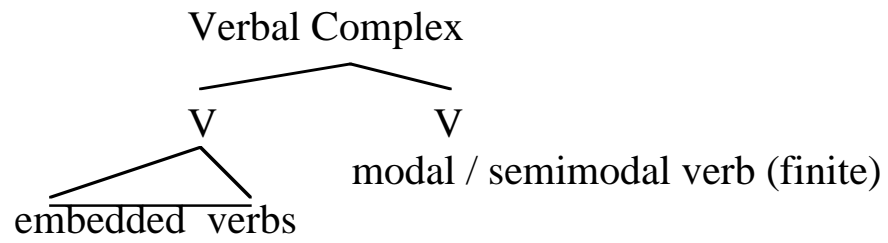

I think that the assumption of more than one transformation leading to a verbal complex is likely to be uneconomic.

This also is an argument against the SUBJECT-RAISING-hypothesis for the German syntax. Why should we lift the subject of the embedded sentence with the result of a verbal complex within a coherent construction? Proceeding on the observation that surface structures with modal and semimodal verbs syntactically have much in common, and given the assumption that the elements of both groups are predicates with an S-argument, I postulate identical lexical features for the modal and semimodal verbs respectively.

But do these features cause predicate RAISING or LOWERING? In the Chomsky-oriented theory it is postulated that movement should always be upwards (thus, movement to the right is forbidden). But consider for example a sentence with a negation as in (30):

(30) John schreibt keine Bücher.

The deep-structure can be something like that:

figure 18

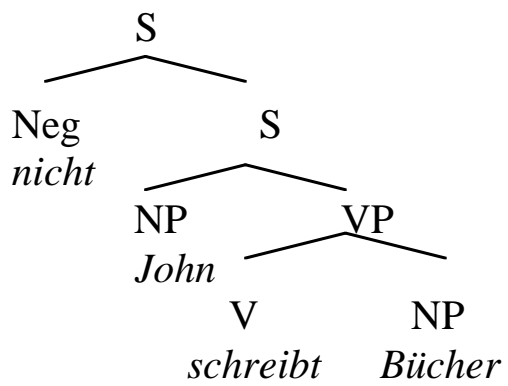

In this case the negation has to move downwards otherwise we would have to move two elements upwards. If nicht is interpreted as a VP-adverbial as in 
figure 19

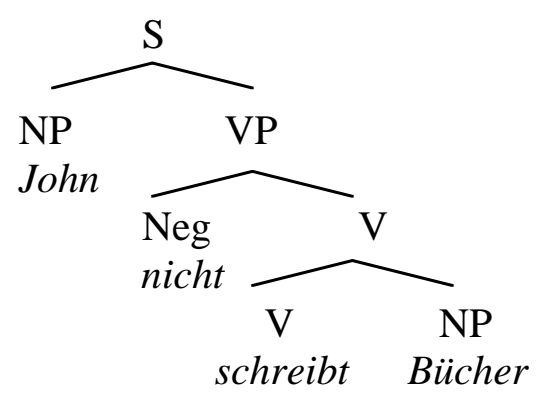

... then indeed there could be the options of RAISING (schreibt) and LOWERING (nicht).

But only the structure in figure 18 represents the logical structure of the proposition: "it's not the case that John is writing books." So why should we use the structure in figure 19 which looks like the structures Chomsky (1995: 140) assumes for English sentences like

(31) John did (does) not write books

There can, there must be downwards movement; it is the most natural movement in the case of (31).

So we have the choice between LOWERING and RAISING, because one transformation leading to verbal complexes is sufficient. If we maintain LOWERING, we would run into problems with the transformational treatment. If we maintain RAISING, we would have to accept VPROJECTION-RAISING in the syntax of German; witness sentences like

(32) a ..., daß du uns hast die Schlacht gewinnen helfen.

b ..., wenn er hätte einem Kind das Märchen vorlesen dürfen.

The structure of the verbal complex in (32)b can be something like this:

figure 20

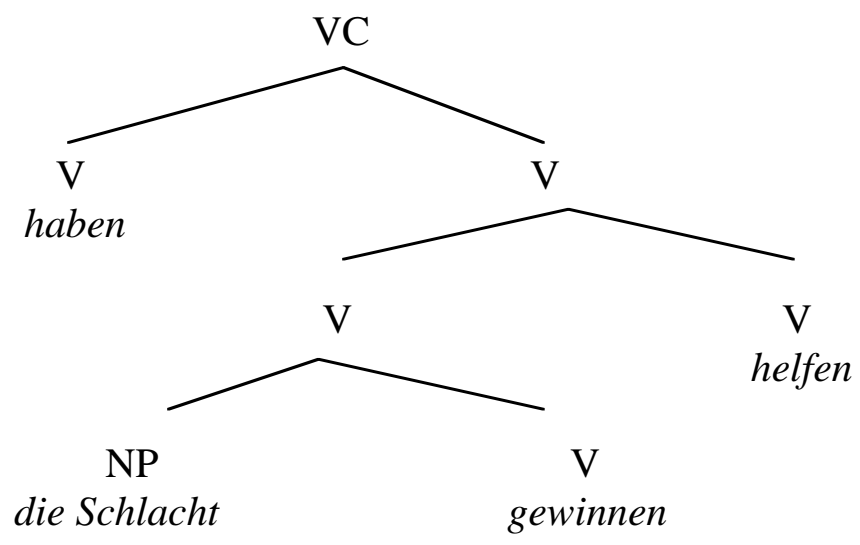

If we want to maintain RAISING in the coherent variant as in ..., daß du uns hast die Schlacht gewinnen helfen then first we would have to form the complex node [Schlacht gewinnen]. This complex node has to climb up in the tree. But this is V-projection-RAISING, a transformation that in it's original intention is not relevant for the German syntax. As argued in Richter (2000:99 et passim), at least for the German sentences the assumption of VPROJECTION-RAISING is not the most obvious one. 


\section{$4 \quad$ No transformations \\ 4.1 Motivation}

I want to bring up the question if it is possible to represent the structures above in a nontransformational grammar, for example in the framework of a categorial grammar. Does the attempt make sense to combine a transformational system like SeSyn with a nontransformational system, for instance by keeping the SeSyn basic-categories (in categorial grammar-like notation) but leaving out its transformational rules, and by applying reductional and other laws from the categorial grammar?

These considerations might be motivated by the attempt to reduce the set of rules (for this point see also Bach (1983: 113) e.g.) (respectively to avoid discussions like the one above about RAISING and LOWERING) and to investigate whether there is a link between transformational and non-transformational systems. The question is, to what extent are mechanisms like LOWERING and RAISING psychologically motivated and whether the choice between these two transformations is a marginal one.

Note: SeSyn is a generating system while a categorial grammar normally is used to parse sentences. But in the following approach I want to bring out a certain correspondence between the basic ideas of the SeSyn-system and a categorial system: the former starts with basic categories (which reflect in a certain sense the syntactic-semantic deep structure) and constructs a surface structure; the latter starts with the same categories and a derivation is sought that ends,say, with the symbol "S".

\subsection{Rules}

The derivations below reflect in principle a process that Seuren (p.c.) dubbed "union with matrix-V", i.e. an element like a tense operator, an auxiliary or a has to combine with the matrix-V. The following examples show a derivation inside the overall frame of a flexible categorial grammar along the lines of only two reduction laws, namely APPLICATION and COMPOSITION. First, these two laws together with the semantic interpretation will be given (see also Moortgat 1988: 11,Wunderlich 1997a:111):

(33) Application

$\mathrm{X} / \mathrm{Y}: \mathrm{a} \& \mathrm{Y}: \mathrm{b}=>\mathrm{X}: \mathrm{a}(\mathrm{b})$

(34) Composition

$$
\begin{array}{llll}
\mathrm{X} / \mathrm{Y}: \lambda \mathrm{y}(\mathrm{f}(\mathrm{y})) \& & \mathrm{Y} / \mathrm{Z}: \lambda \mathrm{z}(\mathrm{g}(\mathrm{z})) & \Rightarrow & \mathrm{X} / \mathrm{Z}: \lambda \mathrm{z}(\mathrm{f}(\mathrm{g}(\mathrm{z}))) \text { and } \\
\mathrm{X} / \mathrm{Y}: \lambda \mathrm{y}(\mathrm{f}(\mathrm{y})) \& & (\mathrm{Y} / \mathrm{Z}) / \mathrm{U}: \lambda \mathrm{u} \lambda \mathrm{z}(\mathrm{g}(\mathrm{u}, \mathrm{z}))=> & (\mathrm{X} / \mathrm{Z}) / \mathrm{U}: \lambda \mathrm{u} \lambda \mathrm{z}(\mathrm{f}(\mathrm{g}(\mathrm{u}, \mathrm{z})))
\end{array}
$$

(35) shows the introduction of a slash which semantically corresponds to an $\lambda$-abstraction.

$$
\begin{aligned}
\text { (35) } \mathrm{X} & =>\mathrm{Z} / \mathrm{Y}: \lambda \mathrm{y}(\mathrm{z}) \text { if } \\
\mathrm{X}, \mathrm{Y}: \mathrm{y} & =>\mathrm{Z}: \mathrm{z}
\end{aligned}
$$

\subsection{Examples}

Let's start with sentences with verbal complexes. In these four sentences the respective governing verb is a modal, a halfmodal, an auxiliary of future and an auxiliary of time respectively: 


$\begin{array}{rllllrr}\text { (36) a } & \ldots, \text { weil } & \text { sie } & \text { das } & \text { lesen } & \text { kann. } & \\ \text { b } & \text {.., weil } & \text { sie } & \text { das } & \text { zu lesen } & \text { scheint. } & \\ \text { c } & \text {..., weil } & \text { sie } & \text { das } & \text { lesen } & \text { wird. } & \\ \text { d } & \text {..., weil } & \text { sie } & \text { das } & \text { hat } & \text { lesen } & \text { können. }\end{array}$

The following formation rules in SeSyn style are necessary to construct a deep structure for the sentences above:

$$
\text { (37) } \begin{array}{ll}
\mathrm{S}^{\prime \prime} & \rightarrow \mathrm{V}_{\mathrm{t} 1} \& \mathrm{~S}^{\prime} \text { INTER } \\
\left\{\mathrm{S}^{\prime}\right. \text { INTER } & \left.\rightarrow \mathrm{V}_{\text {INTER }} \& \mathrm{~S}^{\prime}\right\} \\
\mathrm{S}^{\prime} & \rightarrow \mathrm{V}_{\mathrm{t} 2} \& \mathrm{~S}^{\circ} \\
\mathrm{S}^{\circ} & \rightarrow \mathrm{V}_{\text {main }} \& \text { argument frame }
\end{array}
$$

\begin{tabular}{|c|c|c|}
\hline \multicolumn{2}{|c|}{ argument frame } & rule feature \\
\hline$\&$ & $\mathrm{~S}^{\prime}$ & Lowering \\
\hline$\&$ & $S^{\prime}$ & Lowering \\
\hline$\&$ & $S^{\prime}$ & Lowering \\
\hline$\&$ & $S^{\prime}$ & Lowering \\
\hline$\&$ & $\mathrm{~S}^{\prime}$ & Predicate raising \\
\hline$\&$ & $P \& N P$ & - \\
\hline
\end{tabular}

(the brackets symbolize optionality)

And we have the following lexicon for the lexical elements involved:

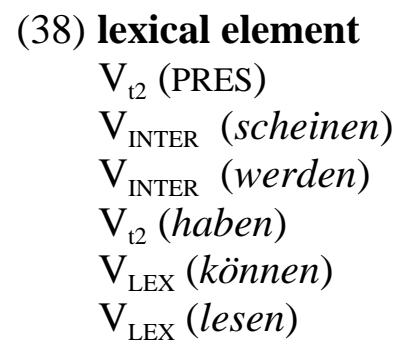

For the purpose of illustrating the formation rules in (37) I give the corresponding structure trees (see also (28) and figure 10) for the sentences (36)a $-\mathrm{d}$ :

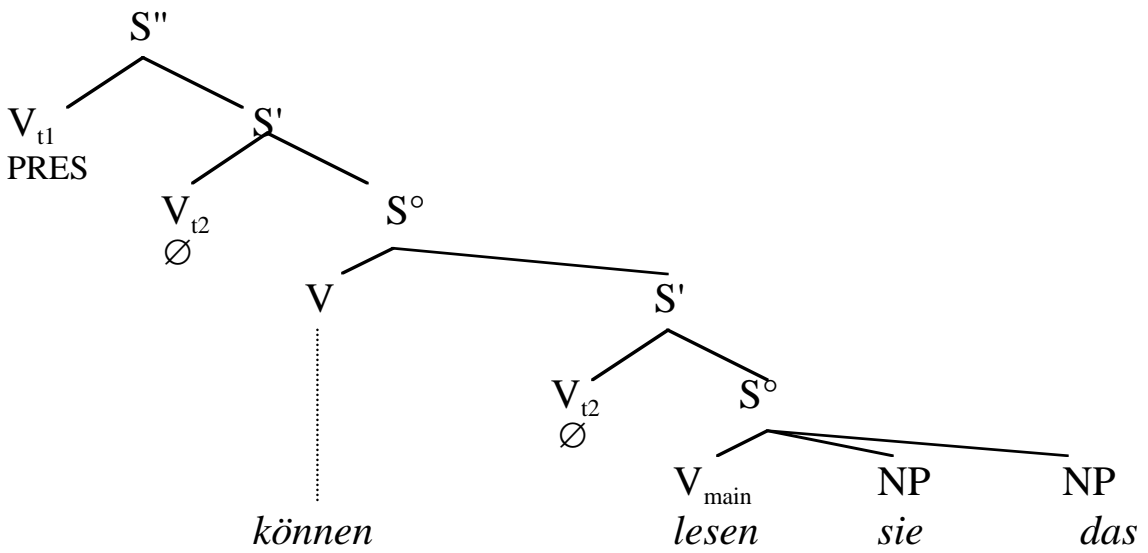

figure 21a (sentence (36a))

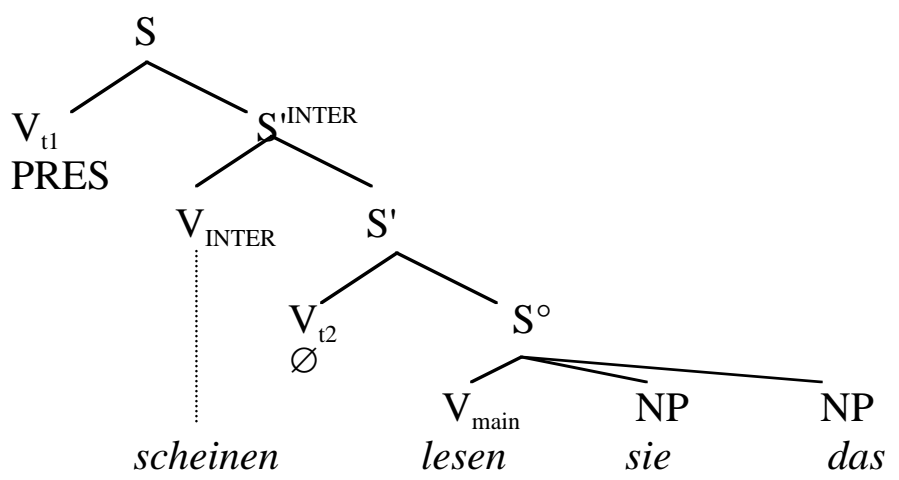

figure $21 b$ (sentence $(36 b)$ ) 


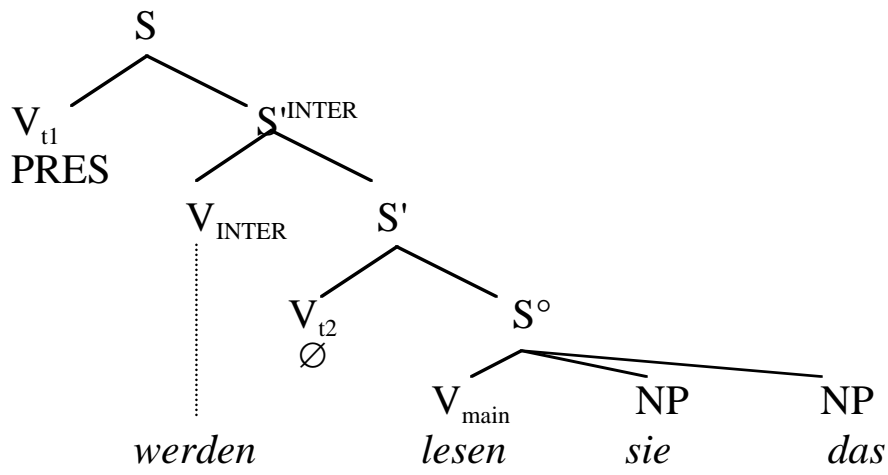

figure $21 \mathrm{c}$ (sentence (36c))

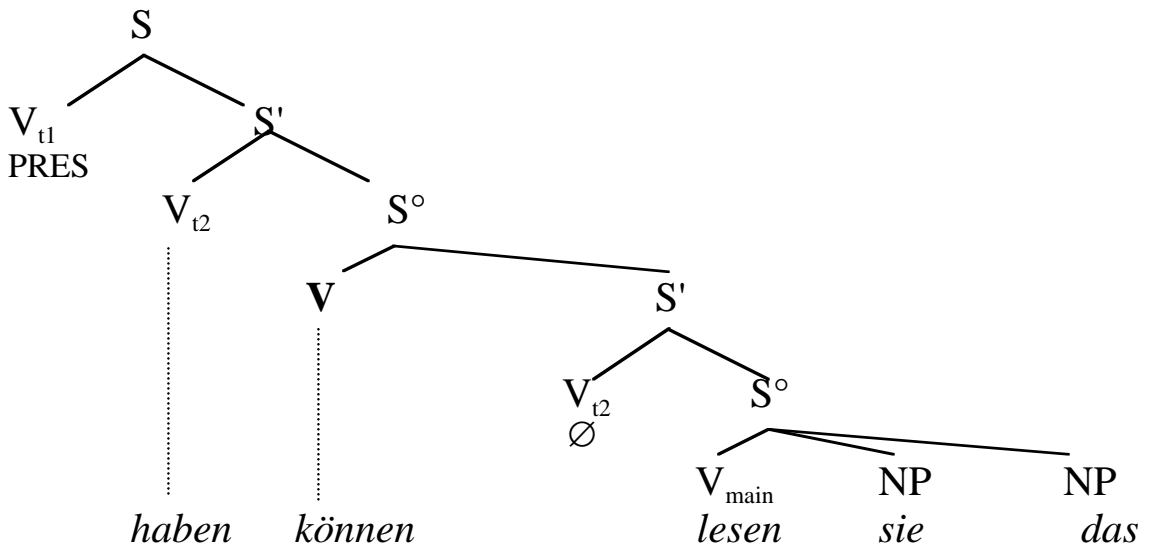

figure $21 \mathrm{~d}$ (sentence $(36 \mathrm{~d}))$

In a categorial treatment we formulate the following dominance rules, which are intended to be equivalent with the rules in (37). Dominance rules don't determine the order of elements; I have disregarded positions for adverbs etc. since the example sentences don't have such elements; moreover the precise feature-combination-mechanisms have to be specified:

$$
\begin{aligned}
& \text { (39) } \mathrm{S}_{[\mathrm{FIN+}+]} \rightarrow \quad \mathrm{S}_{\mathrm{S}_{\text {[INTER:_FIN+] }}} \& \mathrm{~S} \\
& \mathrm{~S}_{[\text {LEX] }} \mid \mathrm{S}_{[\mathrm{INTER}, \text { FIN + }} \quad \& \quad \mathrm{~S} \quad \text { OR } \\
& \mathrm{S}_{[\mathrm{R}, \mathrm{PERF}, \mathrm{FIN}+]} / \mathrm{S}_{[\mathrm{LEX}]} \quad \& \quad \mathrm{~S}_{[\mathrm{LEX}]} \quad \text { OR } \\
& \mathrm{S}_{\text {[LEX,FIN+] }} \\
& \mathrm{S} \quad \rightarrow \quad \mathrm{S}_{[\mathrm{R}, \mathrm{PERF}]} / \mathrm{S}_{[\mathrm{LEX}]} \& \quad \mathrm{~S}_{[\mathrm{LEX}]} \\
& \mathrm{S}_{[\mathrm{LEX}]} \rightarrow \quad \text { lexical element } \& \text { argument frame }
\end{aligned}
$$

"R" means "right-branching". Recall that haben/werden together with certain verbs trigger the so-called Oberfeldumstellung. As said above in paragraph 2 in this case the verb-cluster is hybrid branching (left-right-branching). Werden and scheinen get the feature "INTER" (=intertense position). "INTER" means "intertense-position" and "_" symbolizes a variable, in that the value of the parameter "INTER" can be "SEMIMOD" or "FUT".

In (39) we let out the first rule in (37). Following Bach the inflected forms of verbs are part of the lexicon (1983:111). There we could find the following specification for hat:

(40) hat: $\quad \mathrm{S}_{[\mathrm{R}, \mathrm{PERF}, \mathrm{FIN+}+} / \mathrm{S}_{[\text {LEX] }}$

As a lexical rule the tense operator $\mathrm{V}_{\mathrm{t} 1}$ combines with the category of the haben 


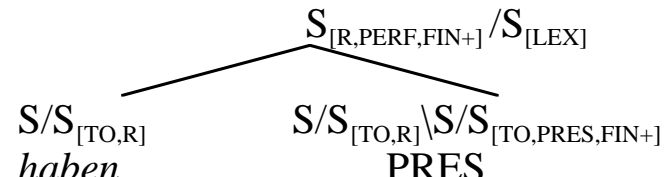

figure 22

The category for 'PRES' is an 'exocentric modifier' as defined by Bach (1983: 108, see also Bouma 1988). The type is

$$
\begin{aligned}
& A / A_{F \neq G} \\
& {[F] \quad[G]}
\end{aligned}
$$

where ' $F$ ' and ' $G$ ' can be clusters of feature values.

All features of the argument have to climb up to the mother node unless excluded. This however has to be the case here. I assume that in figure 21 the mother node does not have the features 'TO' (=tenseoperator) and also not 'PRES' but instead the feature 'PERF'.

We have the following lexical entries for the verbs in (36). Note that the slash is leftdirectional since the finite verb is sentence final in German subordinate clauses:

$$
\begin{aligned}
& \text { (42) a kann: } \quad S \backslash S_{[L E X, R, F I N+]} \quad \text { OR } S_{[L E X]} \backslash S_{[L E X, R, F I N+]} \\
& \text { b scheint: } \quad \mathrm{S} \backslash \mathrm{S}_{\text {[INTER: SEMIMOD,FIN+] }} \quad \text { OR } \quad \mathrm{S}_{\text {[LEX] }} \backslash \mathrm{S}_{\text {[INTER:SEMIMOD,FIN+] }} \\
& \text { c wird: } \quad \text { SIS } \mathrm{S}_{\text {[INTER:FUT,FIN+] }} \\
& \text { d lesen: } \quad \mathrm{NP} \backslash \mathrm{NPIS} \mathrm{S}_{[\mathrm{LEX}, \mathrm{FIN}-]} \\
& \text { e haben: } \quad \mathrm{S}_{[\mathrm{R}, \mathrm{PERF}, \mathrm{FIN}-\mathrm{S}} / \mathrm{S}_{\left[\mathrm{LEX}, \_, \mathrm{FIN}-\mathrm{j}\right.}{ }^{3} \\
& \text { f hat: } \quad \mathrm{S}_{[\mathrm{R}, \mathrm{PERF}, \mathrm{FIN}+]} / \mathrm{S}_{[\mathrm{LEX},, \text { FIN- }]} \\
& \text { g können: } \quad \mathrm{S} \backslash \mathrm{S}_{[\mathrm{LEX}, \mathrm{R}, \mathrm{FIN}-]} \quad \text { OR } \mathrm{S}_{[\mathrm{LEX}]} \backslash \mathrm{S}_{[\mathrm{LEX}, \mathrm{R}, \mathrm{FIN}-]}
\end{aligned}
$$

Since the dominance rules above don't determine the word order we have to formulate rules (e.g. "linear precedence"-rules in HPSG-terminology). To account for the Oberfeldumstellung in (36)d we need a rule like this:

$$
\mathrm{S} / \mathrm{S}_{[\mathrm{R}, \mathrm{PERF}, \mathrm{FIN}+/]}>\quad \mathrm{X}_{[\mathrm{R}]}
$$

( ">" means: "proceeds")

Constructions like (44) are thus excluded:

$\begin{array}{clll}\text { (44) a } & \text { lesen } & \text { können } & \text { hat } \\ & \mathrm{X} & \mathrm{X}_{[\mathrm{R}]} & \mathrm{S} / \mathrm{S}_{[\mathrm{R}, \mathrm{PERF}, \mathrm{FIN}+]} \\ \mathrm{b} & \text { lesen } & \text { können } & \text { haben } \\ & \mathrm{X} & \mathrm{X}_{[\mathrm{R}]} & \mathrm{S} / \mathrm{S}_{[\mathrm{R}, \text { PERF,FIN- }]}\end{array}$

\footnotetext{
${ }^{3}$ The horizontal bar inside the feature structure symbolizes a variable. The notation reminds of the "anonymous variable" in PROLOG.
} 
A double inversion as in

$$
\begin{array}{llll}
\text { wird } & \text { haben } & \text { lesen } & \text { können } \\
\mathrm{S} \backslash \mathrm{S}_{[\text {INTER:FUT,FIN+] }} & \mathrm{S} / \mathrm{S}_{[\mathrm{R}, \mathrm{PERF}]} & \mathrm{N} \backslash \mathrm{N} \backslash \mathrm{S} & \mathrm{S} \backslash \mathrm{S}_{[\mathrm{LEX}, \mathrm{R}, \mathrm{FIN}-]}
\end{array}
$$

can be represented in an LP-rule like:

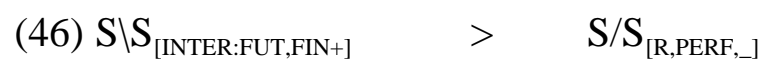

The dominance rules forbid a construction like:

\section{(47) wird lesen haben können}

Figure 23 illustrates that in this case we would get cross-dependencies in the syntax-tree:

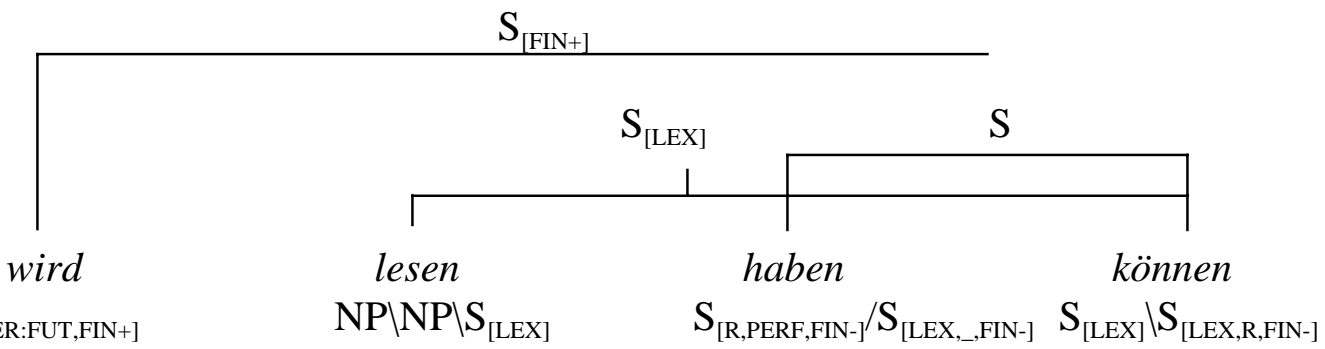

figure 23

The derivation proceeds according to the laws described in (33) and (34). Figure 24 shows the correct representation in a syntax tree according to the dominance (39) and linear precedence rules (43/46):

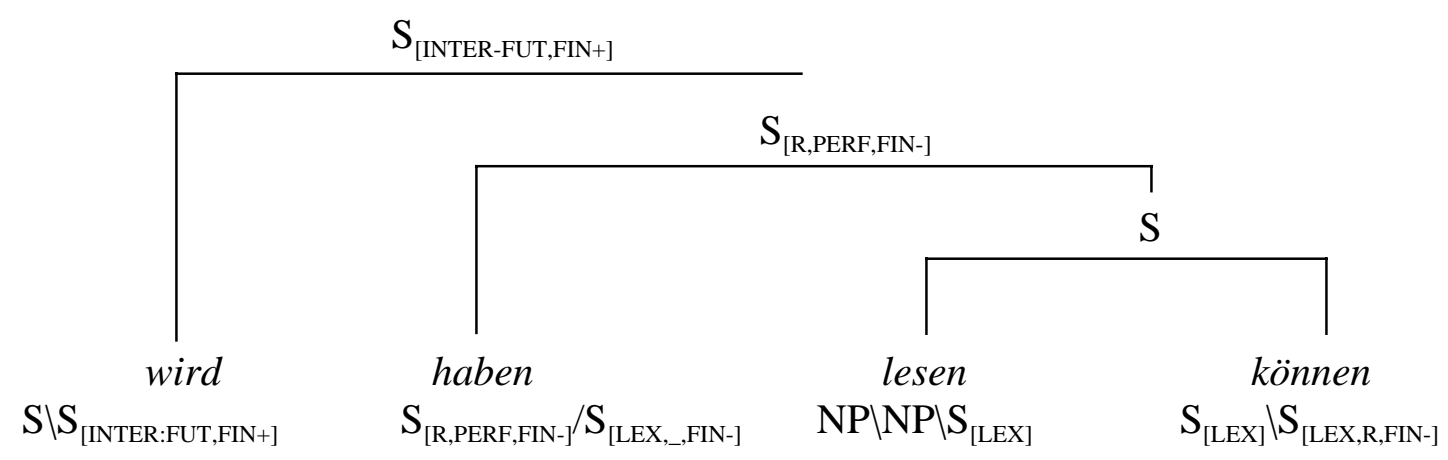

figure 24

For the sentence with Oberfeldumstellung (36)d we roughly get the following derivation along the derivational rules (33) and (34): 


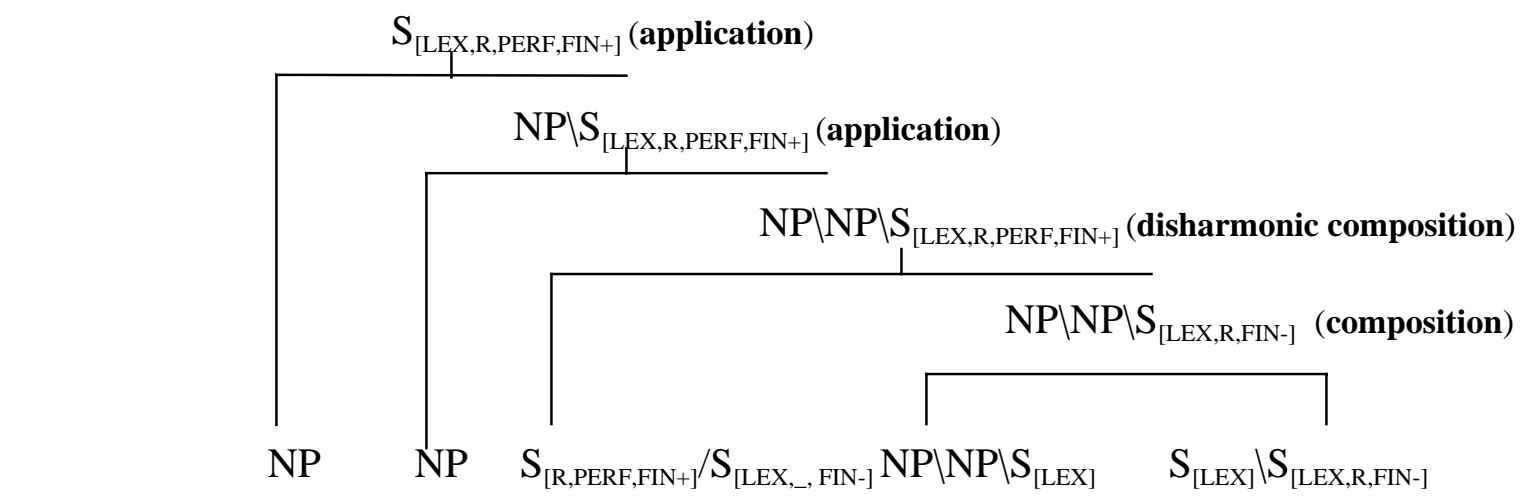

..., weil sie das hat kesen können.

\section{figure 25}

There are no derivational problems with a sentence containing a like in (36)b either:

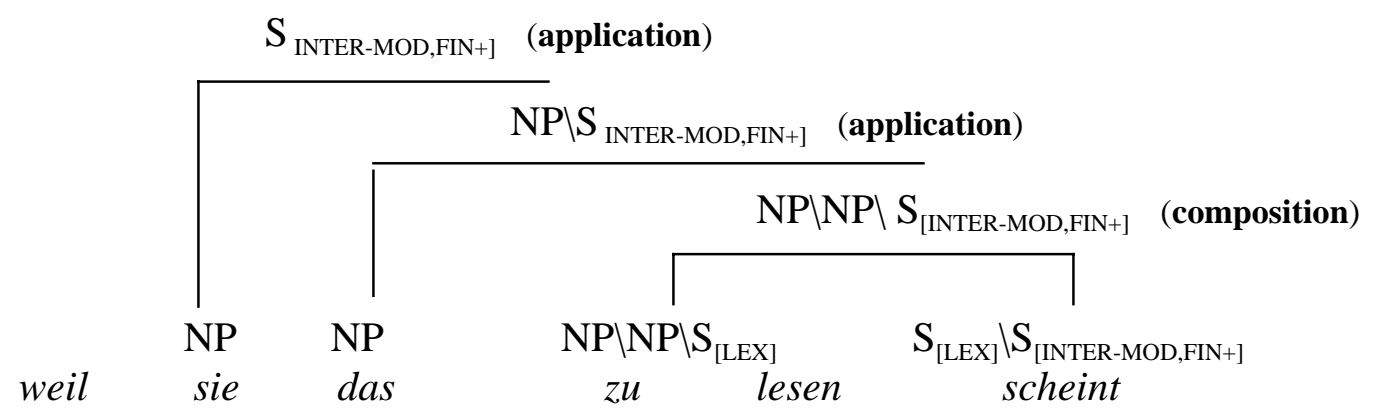

figure 26

The dominance rules exclude that a is the argument of an operator with the category $\mathrm{S}_{[\mathrm{R}, \mathrm{PERF}]} / \mathrm{S}_{[\mathrm{LEX}]}$, i.e. the category of finite or non-finite haben. Moreover, the first dominance rule in (39) says that only one intertense element may occur in a finite sentence. Thus constructions like wird scheinen or scheint werden are excluded.

\subsection{Semantics}

We saw that semimodal verbs have a defective inflectional paradigm, i.e. this group of verbs can not be inside the scope of certain tense operators. The PERF-operator can have definite and indefinite reference to time (sometimes two reference times) and has also the effect that reference time does not equal event time or does not necessarily. It seems that in these cases the use of perfect tense is avoided and simple past is preferred. A semimodal inside the scope of an auxiliary of future is difficult to interpret either. As has been pointed out futuricity can be expressed simply by using the present. Moreover, it has been shown that modal verbs in a certain epistemic meaning show a similar syntactic behaviour like the semimodals.

Following Bach (1983) we can assume additional features (with "t" standing for "truth value") for semantic categories, in this case the arguments.

$\begin{array}{cccc}\text { (48) a } & \text { haben }: & \mathrm{t} & / \\ \mathrm{b} & \text { werden }: & \mathrm{t} & \mathrm{t} \\ \text { [event-time+] } & \end{array}$


'event-time-' means that the event time expressed in the proposition preceeds the reference time resp. that there are two reference points of time, 'event-time-+' means that the event time equals the reference time and 'event-time+' expresses the relationship of the reference time preceding the event time. (48)a says that haben requires an element (which is actually a non finite verb) with the feature 'event-time-(indefinite)' ("the event time is possibly indefinite"). The event time expressed by the subordinated (non-finite) verb is separate from the time expressed by the finite verb in this case the auxiliary (see Janssen 1988:pp.100).

For most verbs the 'event'-feature may be unspecified. This is not the case for the verbs which must get the feature-value-structure 'event-time-+'. Unification of the feature structure of and the auxiliaries of time fails and thus the future and present perfect forms are excluded.

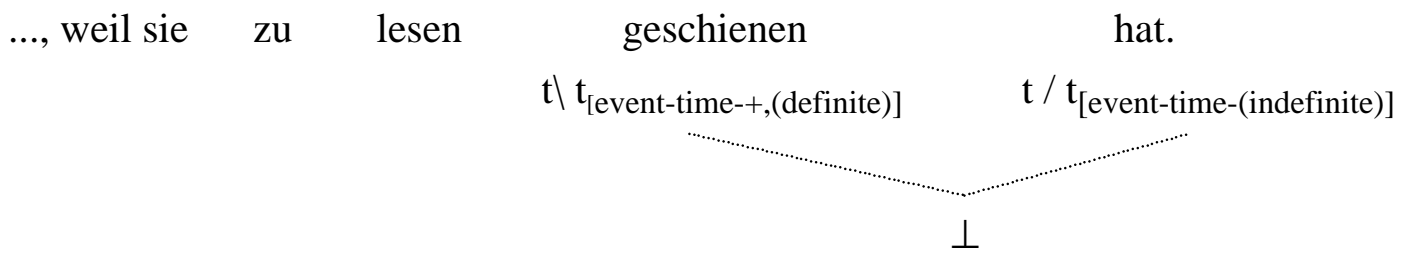

figure 27

For the verbal elements I assume the following rudimentary representation of information in the lexicon ${ }^{4}$ :

$\begin{array}{rll}\text { (49) a } & \text { werden: } & \lambda \mathrm{P}(\operatorname{WERDEN}(\mathrm{P})) \\ \mathrm{b} & \text { haben: } & \lambda \mathrm{P}(\operatorname{HABEN}(\mathrm{P})) \\ \mathrm{c} & \text { scheint }: & \lambda \mathrm{P}(\operatorname{SCHEINEN}(\mathrm{P}))) \\ \mathrm{d} & \text { können: } & \lambda \mathrm{P}(\operatorname{KÖNNEN}(\mathrm{P})) \\ \mathrm{e} & \text { lesen }: & \lambda \mathrm{y} \lambda \mathrm{x}(\operatorname{LESEN}(\mathrm{x}, \mathrm{y}))\end{array}$

The order of argument binding of lesen corresponds with the hierarchy principle (see Bierwisch 1989), i.e. with the Anbindungsreihenfolge (Grammatik der deutschen Sprache 1997: 1303pp,1353pp), e.g. as the first argument of lesen the $y$ will be bound, since $x$ is the subject term and the last to-bind term.

The semantic derivation starts with the combination of the tense operator with the verb that has to be inflected, i.e. scheinen. Then, the representations of the finite verb and the transitive verb have to be combined. Let's consider a derivation for sentence (50):

(50) ..., weil er das Buch zu lesen scheint.

\footnotetext{
${ }^{4}$ This treatment is inspired by Lexical Decomposition Grammar (see Wunderlich 1997a, 1997b).
} 


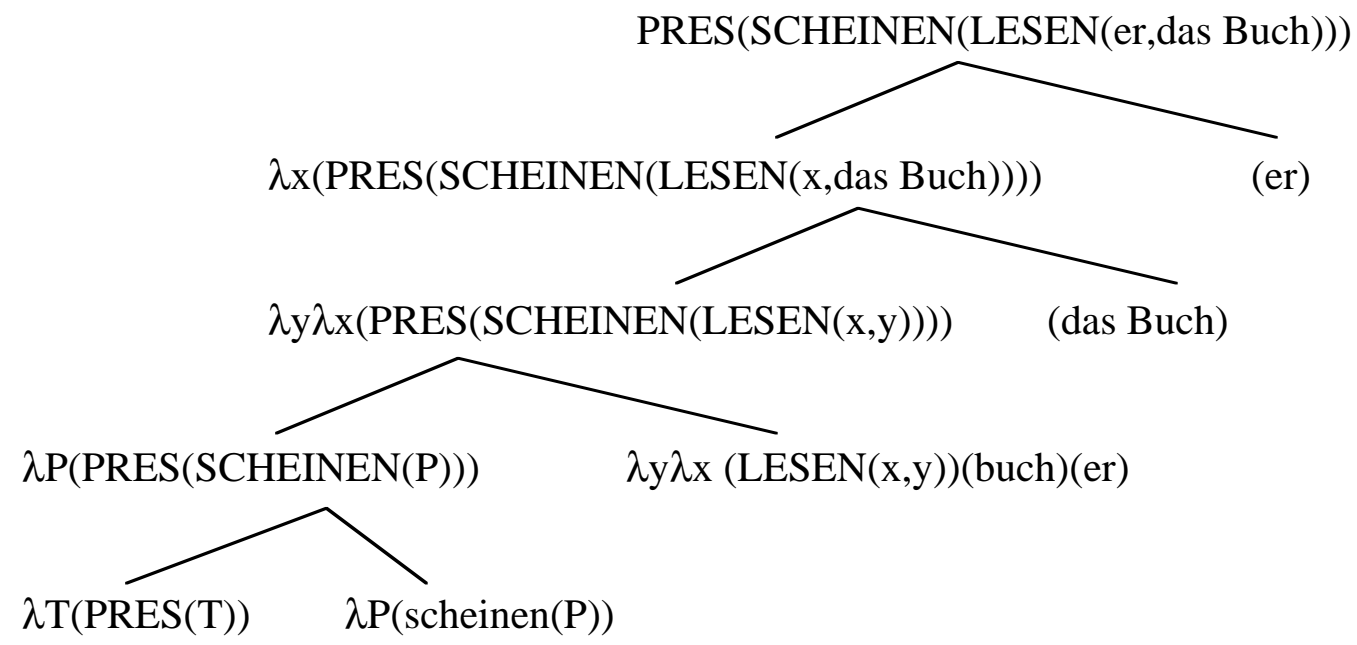

figure 28

The two rules in the semantic derivation are FUNCTIONAL APPLICATION and FUNCTIONAL COMPOSITION. The process is compositional. Another problem in the derivation in figure 28 is that the tense operator precedes the verb and is a sort of prefix instead of, as it should be, an affix.

\section{Conclusion}

In this paper I focused on scope phenomena connected with semimodal (and modal) verbs and mainly on the syntactic behaviour of these groups of verbs. One important question was: why can verbs not have perfect and future tense forms? Taking among other things Reichenbach's tense system as a starting point I tried to point out that the interpretation of a semimodal or a modal in epistemic use is problematic 1. if there is more than one reference time/if the reference time is indefinite or 2 . if the verb in question stands together with an auxiliary of future, which has a certain modal meaning itself.

The comparison of the treatment of these phenomena in the framework of the transformational Semantic Syntax with a non transformational approach (fragment of a categorial grammar) showed, I think, that important transformational rules and principles like LOWERING/RAISING leading to a coherent verbal cluster can be represented in a non transformational grammar economically. The transformational approach needs RAISING and LOWERING (or at least one of the two and in addition to this a rather extended set of rules) for the generation of sentences while in the categorial system we need only two reduction laws, namely COMPOSITION and APPLICATION. It has to be investigated whether the SeSyn-formation rules and the dominance / linear precedence rules are equivalent.

\section{References}

Bach, Emmon (1983): "Generalized Categorial Grammars and the English Auxiliary". In: Heny, F. / Richards, B. (eds.): Linguistic Categories: Auxiliaries and Related Puzzles. vol 2, Dordrecht: 101-120.

Ballweg, Joachim (1988): "Präsensperfekt vs Präteritum im Deutschen". In: Ehrich, Veronika / Heinz Vater (eds.): Temporalsemantik. Tübingen: 81-95.

Besten, Hans den / J. Rutten/ T. Veenstra, J. Veld (1988): Verb Raising, Extrapositie en de Derde Constructie. Research report: University of Amsterdam (unpublished). 
Besten, Hans den / Hans Broekhuis (1992): "Verb Projection Raising in het Nederlands". Spektator 1992: 21-34.

Bouma, Gosse (1988): "Modifiers and specifiers in categorial unification grammar". Linguistics 26: 21-46.

Chomsky, Noam (1995): The minimalist program. Cambridge.

Eisenberg, Peter (1986): Grundriß der deutschen Grammatik. Stuttgart.

Enç, Mürvet (1981): Tense without scope: An Analysis of Nouns as Indexicals. Ph.D. dissertation. University of Wisconsin-Madison.

Geilfuß, Jochen (1991): "Verb- und Verbphrasensyntax". In: Sprachtheoretische Grundlagen für die Computerlinguistik. Arbeitspapiere des Sonderforschungsbereichs 340, Bericht Nr. 11. Wissenschaftliches Zentrum der IBM Deutschland: Stuttgart.

Heidolph, Karl Erich / Flämig, Walter / Motsch, Wolfgang (1981): Grundzüge einer deutschen Grammatik. Berlin.

Hinrichs, Erhard W. I Nakazawa, Tsuneko (1994): "Linearizing AUXs in German Verbal Complexes". In: Nerbonne, John / Netter, Klaus / Pollard, Carl (eds.): German in HeadDriven Phrase Structure Grammar. CSLI: Stanford (no. 46): 11-37.

Institut für deutsche Sprache (1997): Grammatik der deutschen Sprache (3 volumes). Berlin/New York.

Janssen, Theo (1988): "Tense and temporal composition in Dutch". In Ehrich, Veronika / Vater, Heinz (eds.): Temporalsemantik. Tübingen: 96-128.

Moortgat, Michael (1988): Categorial Investigations. Logical and Linguistic Aspects of the Lambek Calculus. Ph.D.dissertation. University of Amsterdam.

Nerbonne, John (1984): German Temporal Semantics: Three Dimensional Tense Logic and a GPSG Fragment. New York/London (=Working Papers in Linguistics, 30).

Oversteegen, Eleonore (1988): "Temporal adverbials in the Two Track Theory of Time". In: Ehrich, Veronika / Vater, Heinz (eds): Temporalsemantik. Beiträge zur Linguistik der Zeitreferenz. Tübingen: 129-162.

Radford, Andrew (1997): Syntactic theory and the structure of English. A minimalist approach. Cambridge. (=Cambridge Textbooks in Linguistics).

Richter, Michael (2000): Verbkonstruktionen im Deutschen. Eine transformationelle Analyse syntaktischer Erscheinungen innerhalb des deutschen Verbsystems im Rahmen der semantischen Syntax. Ph.D. dissertation. University of Nijmegen.

Seuren, Pieter (1996): Semantic Syntax. Oxford.

Vater, Heinz (1975): "Werden als Modalverb". In: Calbert, Joseph P. / Vater, Heinz: Aspekte der Modalität. Tübingen: 71-148 (=Studien zur deutschen Grammatik 1).

Wunderlich, Dieter (1997a): "Argument Extension by Lexical Adjunction". Journal of Semantics 14: 95-142.

Wunderlich, Dieter (1997b): "Cause and the Structure of Verbs". Linguistic Inquiry 1: 27-68. 